\title{
The Iceberg Theory: A Critical Reading of A.A Milne's Tale Winnie the Pooh (1926)
}

\author{
Afnan Turki Al-Dossari \\ Imam Abdulrahman Bin Faisal University \\ $\underline{\text { Afnan.T.Aldossari@gmail.com }}$ \\ Leena Thabit Al-Qahtani \\ Imam Abdulrahman Bin Faisal University \\ Leena.T.Alqahtani@gmail.com \\ Dr Hessa Alkahlan \\ Imam Abdulrahman Bin Faisal University
}

Kahlan1st@gmail.com

DOI: http://doi.org/10.36892/ijlls.v2i2.243.

\begin{tabular}{|c|c|}
\hline $\begin{array}{l}\text { Received: } \\
\text { 12/04/2020 }\end{array}$ & $\begin{array}{l}\text { Abstract } \\
\text { The paper tackles Earnest Hemingway's theory “The Iceberg Theory”, with an }\end{array}$ \\
\hline $\begin{array}{l}\text { Acce } \\
25 / 05\end{array}$ & $\begin{array}{l}\text { emphasis on the omission technique, through which the tip of the Iceberg is } \\
\text { seen; omitting what is underneath the surface, the undetected mass. The study } \\
\text { examines the possible influence of Edgar Allan Poe, who is known to be } \\
\text { conscious of the "Theory of Omission" before Hemingway. Sigmund Freud's }\end{array}$ \\
\hline $\begin{array}{l}\text { Keywords: } \\
\text { Iceberg, Hemingway, } \\
\text { psychological } \\
\text { disorders, Winnie. }\end{array}$ & $\begin{array}{l}\text { psychological perspective, as well, for he studied the different levels of the } \\
\text { unconscious entity of his patients. The research concludes with an analysis of } \\
\text { the life of A.A Milne and his tale "Winnie the Pooh", its characters' true nature, } \\
\text { and a possibility of each one of them having underlying purposes } \\
\text { unintentionally set by the author to represent different psychological disorders }\end{array}$ \\
\hline
\end{tabular}

\section{INTRODUCTION}

Ernest Hemingway (1899-196) is a celebrated American modernist writer and journalist. He won the Pulitzer Prize for his hard efforts in fiction, and at fifty-four he was awarded the Nobel Prize. The influence of his stylistic technique created the genre of detective or mystery novels. Being a journalist, he faced limitations that restricted his writing from being detailed by shedding light on only the surface and what is clearly stated and omitting what is underlined. This technique may invite the reader to come up with his own interpretations of the text. As a reporter, he proved to have a unique "Minimalistic" style which may be the influence of Poe, Freud, and others. He refers to this new method of writing as the "Iceberg Theory". He treated a tale to an iceberg, in which only the tip is detectable, but underneath the surface, there is an undetected mass. The first time Hemingway mentioned this principle was in his book Death in The Afternoon. later in an interview with George Plimpton, he says: 
"I always try to write on the principle of the iceberg. There are seven-eighths of it underwater for every part that shows. Anything you know you can eliminate, and it only strengthens your iceberg. It is the part that doesn't show. If a writer omits something because he does not know it then there is a hole in the story" (Hemingway, in Plimpton 1963 [1985]: 133) ${ }^{i}$

Hemingway speaks about this technique comparing it to that of poetry, saying: "It is much more difficult than poetry"ii. It is a prose that has never been written"iii. In writing poetry, the difficult part comes while trying to come up with words that reflect certain images, to make it reach its full potentiality in influencing the readers, this includes the language to be rhythmic, simple and direct. Whereas writing with the iceberg principle requires the work to be limited by creating ideas, feelings, and attitudes with using only a few words that could imply different underlying meanings. Therefore, while adapting to the iceberg style, the writer is obliged to reduce the number of words for the work to be direct, neat and simple, yet loaded with many unsaid ideas and feelings, to write "prose that has never been written".

Hemingway has elaborated on The Iceberg principle:

"A few things I have found to be true. If you leave out important things or events that you know about, the story is strengthened. If you leave out or skip something because you don't know it, the story will be worthless. the test of any story is how very good the stuff is that you, not your editors, omit." Also, he stated: "Good writing is true writing. If a man is making a story up, it will be true in proportion to the amount of knowledge of life that he has and how conscientious he is; so that when he makes something up it is as it would truly be. If he doesn't know how many people work in their minds and actions, his luck may save him for a while, or he may write fantasy. But if he continues to write about what he does not know about he will find himself faking. After he fakes a few times he cannot write honestly anymore" (Hemingway 1935: 215) ${ }^{\mathrm{iv}}$

According to Hemingway, if the author keeps writing about things that he does not know of, he will not be able to write "honestly". He suggested that the writer must be honest, honesty in writing is to tell the truth, and he should be writing about the "...knowledge of life that he has". The verses and imageries in literary works should be the one-eighth above water, while the sentiments and thoughts behind the words make the seven-eighth underwater. Hemingway explains that:

"The dignity of movement of an ice-berg is due to only one-eighth of it being above water. A writer who omits things because he does not know them only makes hollow places in his writing. "’v

Hemingway's Iceberg theory is a principle that he formed and applied to his short stories, and it is the most exceptional technique he retained as an author. It is one of his finest offerings to the stylistic techniques of the short story. Though the Iceberg theory, which adapts the omission technique, was coined by Ernest Hemingway, yet, Edgar Allan Poe was already practising the same technique while advertising his "Unity of Effect". This technique is apparently manipulated in Hemingway's late writings, maybe unconsciously, and developed into a theory. The technique of the Iceberg, by concept, is very similar to Poe's "Unity of Effect"vi, from which almost all Poe's short stories' emotional impact is created. According to 
Silvia Ammary vii, Poe's conception of the omission technique, which form the basis of Hemingway's Iceberg theory, shows that Poe's impact on the development of writing narrative literature evident and concrete.

Hemingway's own story of formulating this theory is uniquely compelling. His profession experienced an obstruction when his first copies in a suitcase were stolen in a train station. Due to this break in his profession, Hemingway created his Iceberg principle. His new style was established to speak on two scales concurrently; the obvious and the implied. As the iceberg correlation proposes that the deceiving surface of any story is, in fact, covering a hidden, more massive complicated underlying. The theory of the Iceberg can be seen from a psychological perspective, as well. Sigmund Freud's new approach to psychology draws attention to the different levels of the unconscious entity. According to Kenneth Johnston ${ }^{\text {viii }}$, Ernest Hemingway's new writing style and Sigmund Freud's modern psychology share hugely parallel norms.

\section{THE ICEBERG THEORY \\ 2.1. Hemingway}

He later said that from all of his writings, what he made up, was his most significant writing. At fifty-three, in May, His writing was how modern writing should be. Most of Hemingway's stories were written and published before he turned twenty-five. His significant style of writing has influenced most of American writers. With all that Hemingway has been through in his life, either if it was war, multiple accidents, physical injuries, and mental illness. It all did not affect his literary legacy from being permanently fixed in the history of literature.

\subsection{The Iceberg Theory}

Hemingway was invited to attend the Lausanne Peace Conference in the winter of December in 1922. He asked his wife Elizabeth Hadley, to accompany him. Hadley packed all of his handwritten notes, originals, copies, of a novel in progress that he began writing in Chicago, into a single suitcase. When she arrived at the train station, right before the train was to depart, Hadley rushed off the train to buy some water, leaving the bags unattended. When she returned to her compartment, she found that a thief had stolen the suitcase with all of Hemingway's writings. The loss was a terrible shock to Hemingway, and it prevented him from writing for four months, until April 1923 when he wrote another story Out of Season. Despite the loss of his uncompleted novel, he obtained a high spirit and was not discouraged about his literary future. As a result of that devastating incident, Hemingway successfully built on the Theory of Omission, which states that the new writings represent the tip of an iceberg, where the simplicity and clarity of which are devious. There are unseen dimensions to the external level of the story which are not presented frankly, yet, perceived and acknowledged by the reading process. The loss of all the complete manuscripts of Hemingway's stories made him economize the number of words in his works and to present only the essentials, and to give the readers the space to interpret the text in their creative manner.

The formation of the Iceberg theory was influenced by Hemingway's own career as a journalistic. He condensed his newspaper articles and reports on direct incidents since he faced 
limitations that restricted his writings from being detailed due to the tight space. Hemingway's style is considered minimalistic because he only focused on the superficial elements while omitting what is beneath. Moreover, he believed that the core of the story must not be revealed to the readers but should rise through implicitly. To properly use the iceberg principle, the author must know the whole spectrum of the story, but only writes an eighth of it, to which it could be compared to the tip of an iceberg that shows only a small part of itself above the water. The iceberg principle could be used in mystery stories where the levels of the plot are omitted, and only the essentials are given. Although this writing style is based on the idea of Omission, it is considered to be the style of "indirection, proposition, and implication" technique permitted Hemingway from revealing the real story, yet at the same time to cover the truth. Hemingway modified his stories so many times and substituted whatever he thought to be of less essentiality, which provided him with the opportunity to compress his writings. He was cautious about the use of language in his works were, he always wrote slowly and revised wisely, omitting, exchanging and experimenting with syntax to see how a sentence could convey all the dimensions of meaning using fewer words. Hemingway was a great artist and craftsman; thus, he was conscious of the difference between the two forms of writing where he could describe the surroundings, not only as a journalist by reporting the truth in a simple yet sophisticated manner, but also as a creative author who had to invent things and not to rely entirely on facts. Hemingway's journalistic career has affected his writings, one way or another, because he knew each aspect of truth that his writings are revolving around. Yet, he only wrote what he thought was important, leaving out unnecessary details to give the readers a chance and space to individually interpret the text creatively.

"The Principle of Omission" is another term for the iceberg theory. To write in the standards of the iceberg theory, you should obtain the skill of omitting the events and what you already know about. The best presentation of Omission is the Narrative style and the Telegraphic dialogue of Hemingway. During his late years, he wrote The Art of the Short Story, an unpublished essay where says:

\section{"A few things I have found to be true. If you leave out important things or events that you know about, the story is strengthened. If you leave out or skip something because you don't know it, the story will be worthless. the test of any story is how very good the stuff is that you, not your editors, omit.". (Hemingway, 1959, unpublished manuscript) ${ }^{x}$}

Accordingly, he believes that the writer should omit the things he knows. Yet, the readers can recognise the same things that were omitted by the writer as if they were written. A writer should portray his intellectual thoughts through the mouth of exaggerated characters that were constructed from the writer embraced experience, from his imagination, knowledge, senses, and whatever shaped to became who he is. If he portrayed it so well and was able to get them all together, he will have more than one dimension and his musings will have a huge impact and will last long. A good writer is not naturally born with the ability to write significantly or with the knowledge of how to do so. Instead, he is born with the ability to learn how to write great passages more than any others, and with the wittiness to distinguish what he should accept and reject from what was already presented to him as a knowledge. Of course, there are some things a good writer cannot learn quickly. They take time. A life worth to be exact. They may seem as simple things, but they are praiseworthy, and the only precious heritage one can leave 
behind because they take one's life to acquire them. The next writer can gain knowledge from every previous novel that has already been written by a good writer. However, the next writer should at least have a little bit of knowledge and experience to know what he can take from a previous novel that shall benefit him in his up-coming writing.

In an interview with George Plimpton in 1950s, Ernest Hemingway noted that "the principle of the iceberg" is the "emotional power" of his fiction. Like the iceberg, it hovers with only a tiny part of its mass showing on the top, while the larger mass of it that contains the vast portion is hidden under the water ${ }^{\mathrm{xi}}$. Therefore, it attracts our attention precisely just because it is hidden. Based on Hemingway's explanation, a summary can be made for the "iceberg theory"xii: the iceberg principle, is creating a distinctive image with the brief and Minimalistic style of writing, the emotions and the beliefs of the writer are built-in in the most significant extent of the image. The writer's thoughts are overwhelming, although its deeply buried but not incomprehensible; thus, the emotion is overflowing, implied but not visible. If the sensibility of the writing is combined skillfully, the readers will be left to explore the sentiments and thoughts in work through the sense of these different images. According to Hemingway, the words and imageries in a literary work are the one-eighth above water; on the other hand, the sentiments and thoughts are hidden between the lines making the seven-eighth underwater.

Daniel Wood ${ }^{\text {xiii }}$ Tells the story of the writing of one of the most well-known of Hemingway's short stories using his Iceberg principle while having dinner with friends. A story with many details omitted, he even wrote it using only one face of a paper napkin. In fact, the little napkin was precisely the reason behind the extreme briefness of that story. He bet his friends ten dollars each that his story on this small napkin could hold an entire short story. His friends agreed to bet against him due to the absolute audacity of his proposition but, under a minute. Hemingway ended the challenge by writing a story on a napkin, gave it to the friends, impressed them with his skillfulness, and took the prizes. It was one of the most fundamental and the most legendary of his iceberg stories; "For Sale: Baby Shoes, Never Worn". Those few words validate the powerful effect of the "iceberg principle"xiv as formulated by Hemingway in its most excellent form.

This story had three possible implied meanings: the first it concludes that an infant has died, though both the birth and death of the infant were not represented in the text but, implied under the surface. From the mother buying the shoes, it gathers her delight and nervousness and what she must have gone through in her expectation of motherhood. From this expectation, we understand the tragedy that she faced when the baby arrived stillborn. On another interpretation, it assumes that the infant's death has left the mother penniless and seeking financial help; otherwise the mother would not be announcing the sale of a thing as valueless as a baby shoe. On further reflection, recalling the end of Hemingway's novel A Farewell to Arms, we may understand that the father is the one who puts up the sales advertisement and that he is the one who went through the trauma of losing both his baby and its mother in the process of giving birth. On the other hand, recalling another of Hemingway's most important stories, Hills Like White Elephants, and suppose that the infant's mother purchased the shoes when she knew that she was pregnant, but that the infant's father has pressured her to get an abortion.

\subsection{Edgar Allan Poe's “Unity of Effect" and Hemingway's "Iceberg Theory".}


The main principle of the Iceberg theory, as formulated by Hemingway, is that of Omission, which suggests that the writer should omit the things he knows of, and the readers can identify the things that were omitted as if they were written. Only half the truth is showing. It worth noting that Edgar Allan Poe manipulated this principal even before Hemingway's theory of the" Iceberg". Poe's "Unity of Effect"xv, which depends on the omission technique, may consciously or unconsciously, influenced Hemingway's short stories written after the Iceberg theory. However, there is no reference to such influence in any of Hemingway's biography. Yet, both writers, Poe in his essay The Philosophy of Composition(1846), and Hemingway in George Plimpton's interview back in 1963 share the concern of how a writer achieves and creates his desired effect on a reader in a short story. The significant effect of Hemingway's theory is on the reader's involvement, and thus, interpretation, of the story depending on the minimum details placed on the "the tip of the iceberg"; the story was written part. Similarly, Edgar Allan Poe encouraged what is called the unity of effect in writing. He believes that there are standard writing features that could help the writer to reach whatever emotional impact he wants to impose on readers. For him, "the short story cannot require more than an hour or two from the reader," for the "unity of effect" to be reached successfully. Poe believes that since the "short story writer has minimal space to draw the reader into their story." ’vii the writer must enjoy the skill to guarantee a purpose to every sentence. He must not take his time illustrating a scene and should not let the plot to discuss the psychology of the characters fully. "The short story writer should intimate every single element in the story whether it was the setting, characters, diction, images, and themes. "xviii And the reader must dig out the rest. Poe has excluded lots of buried elements in the story to leave space, so the readers could have the chance to fill them in. The reader should understand the importance of Poe's words since he sees the weight of every sentence of a story.

Hemingway's principle of omission is, thus, not far from the influence of Poe's unity of effect. Both share the belief that a short story must have so little details of the events to reach a specific impact on readers.

\subsection{Hemingway's Iceberg Theory and Sigmund Freud's Approach to Psychology.}

According to Kenneth Johnston, Hemingway's new writing styles and Sigmund Freud's modern psychology share some extremely related norms ${ }^{\mathrm{xix}}$. "The Iceberg" term is usually used in psychology to analyze a person's attributes, inner feelings and behaviours. Ernest Hemingway successfully demonstrated how the same features of an iceberg could also be used in literature as it is manipulated in psychology. Thus, he empowered his writings with two parallel scales of interpretation. His semi-autobiographical book A Farewell to Arms is written with the Iceberg principle in mind. His new literary technique was intended to connect on two scales concurrently, the obvious and the embedded, and as the iceberg analogy proposes, what is reflected upon that apparent, dull surface is only the tip of that iceberg, hiding a more broad and complex value beneath. According to Freud's new psychology, the mental structure and its profundity and the way the thoughts and emotions are submerged in the unconscious and how these buried thoughts are repressed but often glimpses of those memories and

would rise to the surface of the awareness or what Freud termed the "consciousness"xx. 
The theory of the Iceberg can be traced in Hemingway and Poe's achievements in literature as well in the then-new psychological approach of Sigmund Freud to his clinical cases. Freud's new psychology has dealt with the different levels of the unconscious entity of his patients; the visible level, or the tip of the iceberg which represents the conscious, and the implied level which represents the unconscious. Freud, thus, applying the main principle of the Iceberg theory. Reading AA Milne's Winne The Pooh with the lens of the Iceberg theory would help in transgressing the tip of the iceberg that shows only the simplicity and innocence of the characters which are just a mask for what is beneath the surface and to dig for the characters' nature, and their potential different psychological illnesses.

\section{A.A MILNE'S TALE WINNIE THE POOH}

\subsection{A.A Milne (January 18, 1882- January 31, 1956)}

A Milne is a British writer and a veteran who was born on in London. He was married to Dorothy and their son, Christopher Robin, was born in 1920. While Milne was studying Mathematics, he wrote for the scholar's magazine. After graduation, the realization for the love of writing stroke him. So, he moved to London, and in 1906, he started to write for Punch magazine. After his services in World War I, Milne wrote his first play WurzelFlummery in 1915. Later on, in 1920, he successfully began his profession as a writer. He wrote plays, poetry, novels, and many collections for adults. However, he is mostly remembered and known for Winnie the Pooh, after which he reached his greatest success in 1926, with its publication. His name was always associated with children's books ever after. The book narrates the adventures of Christopher Robin, a boy named after Milne's son, and his animal friends, likewise, were originated from his son's toys. Winnie-the-Pooh was the main character, accompanied by sad Eeyore, a nervous Piglet, an energetic Tigger, an obsessive Rabbit, a knowledgeable Owl, and the kindhearted Kanga and her baby Roo.

\subsection{Winne The Pooh}

Milne served both World Wars. When he returned home, he spent many years recovering physically from the war. When his son Christopher was born, he stopped writing. It was a therapeutic way to handle his post-traumatic stress, and to be the best father and to take care of his boy. He used to write a lot about war and how much he hated it. Before the war, he lived the perfect life, but after it, he was snatched from it all. War affected him negatively. Many soldiers after wars develop PTSD (Posttraumatic Stress Disorder). There is a possibility for him to be psychologically damaged from the war, and that caused him to develop PTSD. There were many casualties in the war and Milne's friends were among them. Bodies were piled around where soldiers fought, lived, and died. Milne was hunted throughout his life with nightmares of war. He frightened Christopher as a kid when the exploding of balloons made him take cover. Or how he was confusing the sound of a flock of buzzing bees with flying bullets. He spoke about how he became super sensitive and cannot go through another war.

One day, Milne and his son Christopher went to the Zoo, where they spotted a small bear named Winnipeg. The bear met many visitors, but the path of children's literature was changed forever by only one visitor. Christopher loved Winnie and decided to change the name 
of his stuffed bear from Edward to Winnie. Milne was finding it hard to explain to his child the harsh reality. But he thought that the only way possible is through his writing. And he took inspiration from his child and Winnie (Pooh was added to 'Winnie' due to the bad smell of the original bear) and his other stuffed animals. He was writing stories about their adventures in the woods behind their home. Eventually, A.A Milne wrote Winnie the Pooh in 1926. What inspired the magical world of Winnie is the relationship between A.A Milne and his son.

Milne has attempted to omit the harsh postwar reality from his son, and only to show a part of it. Yet, he was creative enough to present the whole spectrum of truth in a delicate way on the surface that is child friendly, by presenting this innocent world yet, with the dark hidden side underneath; by showing glimpses of the characteristics of PTSD as a result of the war and by moulding them into the characters of the story. Part of the book's success is that the characters are based on real people like Veronica Rushworth-Lund, the childhood friend of Milne inspired Piglet, and Olive, Christopher's nanny. A real bear in Winnie's case, and a real place called the Ashdown Forest where the Milnes lived, inspired writing the Hundred Acre Wood. The Hundred Acre Woods is filled with stuffed animals which each one of them portrays a child-friendly illustration of a characteristic of PTSD. The characters had different psychological disorders; Milne could have based them on some of the soldiers he saw in his life who had shown symptoms of PTSD. As suggested by some psychologists ${ }^{\mathrm{xxi}}$, each character has their deficits, starting with Owl's memory loss, Piglet's paranoia, Tigger's impulsive behaviours, Kanga's overprotection, Roo's introversion, Eeyore's depression, Rabbit's perfectionism-caused aggression, and lastly, is Winnie, who is written as a guide for Christopher into the Hundred Acre Woods, Milne's mind. The illustrations and the text of the Hundred Acre Wood animals, and the young human captured the innocence and delights of childhood, but with underlying depression and sorrow.

\subsection{Character Analysis}

With the omission technique in mind, Freud's treatment of the unconsciousness of psychological problems can be applied to analyze stories like A. A Milne's Winnie the pooh where the characters were showcased with trivial typical characteristics and keeping the mysterious nature of their reality hidden, just as the iceberg appearance. A close reading of the biographical details about Milne, particularly his war experience would reveal that it might have inspired him to create the characters of the story to showcase different psychological illnesses. As a result, the life represented in Winnie the Pooh may not be as innocent as it is portrayed.

Many generations of readers have admired A.A Milne's cheerful and lighthearted collections of Winnie the Pooh stories. The story presents little boy adventures, with his animal friends in the Hundred Acre Woods. The story appears to be peaceful and harmless, and there could not be much of a complexity to it since it is a children story, however, keeping the iceberg theory in mind, it appears that on the surface of the story, an innocent world is portrayed; where Christopher Robin is happily living surrounded by his loving animal friends. On the more profound meaning, perspectives have changed throughout time, and it is apparent that these stories have a dark underside of extremely disturbed individuals; thus; many theories have offered different interpretations of this story. One theory state that Winnie the Pooh characters were created based on various mental illnesses. This theory is to be examined to evaluate its validity.

\section{A. Winnie}


One of the main characters is Pooh. According to Shea et al ${ }^{\text {xxii }}$, he shows numerous indicators of psychological disorders. The first one is Binge Eating Disorder. Looking at the symptomatic standards, people will tend to have a repetitive episode of binge eating. It means the person will be eating a large amount of food, more extensive than what an average person will be eating in a similar duration of time and situation; the diagnosed will have no control over how much they are eating nor stop it. People with BED tend to eat faster than usual, and they will eat a lot of food until they feel uncomfortably full even if they were not hungry from the start. Some will eat alone due to the embarrassment of how much they eat, disgusted with themselves and feeling guilty afterwards. Pooh is always eating honey and still wants more honey. He will be carrying honey with him all the time, and if he finishes what he has, then he will be in his way looking for more and doing dangerous things to get his hands on some. Whenever he eats a large amount of it, he will either oversleep or feel guilty as if he committed something wrong. But that will not stop him from eating whenever possible. Also, Pooh shows major impulsivity whenever he sees honey; he will try to take it. One time he wore a yellow raincoat as an attempt to hide. This reflects more on the possibility of cognitive impairment, an obsessive fixation on honey, evident obesity, and the repetitive behaviours will cause an obsessive-compulsive. Milne's creation of this character was considered a way to represent many psychological disorders yet, camouflage them by omitting some details of the characteristics forming Pooh. Pooh's open appetite and nervous eating are aspects of Milne's own life hidden in the story.

\section{B. Piglet}

Piglet is a fictional animal figure in Winnie The Pooh that is based on the original plush toy animal of Christopher Robin Milne. In the book's illustration, Piglet is presented as a tiny pinkish pig, and given human properties such as being loving, kindhearted, dreamy, loyal and polite. He is known to be having many fears, yet he could be courageous sometimes. He is known to be the most helpful to his friends, for example, Piglet gave his friend Owl, his treehouse when Owl's house blew down then Piglet moved in to live with his friend Winne. Piglet loves to go on adventures with his best friends Winne and Christopher Robin and what he always says the first thing when he wakes up every day is "I wonder what's going to happen exciting today?"xxiii. This is the innocent shallow exterior of his character that is shown throughout the story, however; with the iceberg theory in mind, according to Shea et al ${ }^{\text {xxiv }}$, Piglet's character appears to suffer from a mental illness. Milne has designed this character to present the aftermath of the war, of people being psychologically damaged yet; he embodied the harshness of the war into a child-friendly illustration. Milne's creation was designed to present a psychological disorder yet; he was keen enough to hide this aspect by only presenting glimpses of the reality behind this character, starting with Piglet's pinkish colour which could reflect his constant shyness and nervousness to his distorted pitch due to his fear of the world surrounding him. The hidden aspects of Piglet's character in the story, are him being always anxious, embarrassed, nervous, restless and tense, moreover; according to some psychologists, the unseen interior of Piglet's character seems like he is suffering from Generalized Anxiety Disorder. According to Mayo Clinic ${ }^{\mathrm{xxv}}$, GAD is associated with symptoms including feeling excessively restless, weariness, difficulty concentrating, irritability, muscle tension, sleep disturbance, over worrying and feeling anxious most of the time in social events. For GAD, these symptoms are associated with the person for at least six months to be diagnosed with 
GAD. Piglet's character has developed a lot of the previous symptoms of GAD in the stories. He was portrayed as being the most sacred character of all, as well as being uncomfortable and hesitant in all situations. He always stutters when he talks because he is frightened, he is the first always to express his worries and to look at the darker side of every event. He is known to be a pessimist that expresses how bad outcomes could happen to everyone; he is always anxious, nervous, overthinking and shaking of fear of the surroundings. In one of the tales, Piglet was surrounded by water and trapped on the top of a tree with the water gradually reaching to him. He expressed how he felt nervous, terrified and was worried that the water would reach his bed:

"It's a little Anxious," he said to himself, "to be a Very Small Animal Entirely Surrounded by Water. Christopher Robin and Pooh could escape by Climbing Trees, and Kanga could escape by Jumping, and Rabbit could escape by Burrowing, and Owl could escape by Flying, and Eeyore could escape by - by Making a Loud Noise Until Rescued, and here am I, surrounded by water and I can't do anything. "xxvi

Piglet's over-worrying and self-degrading are showcasing his desperate way of thinking regarding his situation.

\section{Christopher Robin}

The only leadership offered in the community of the Hundred Acre Woods is from a young boy called Christopher Robin (Rachel Smith) ${ }^{\mathrm{xxvii}}$. Christopher has not exhibited any diagnosable disorders as yet, but there is a possibility of Dissociative Identity Disorder founded in his character. It means that there is a disturbance in identity depicted by having more than one persona. An interference in identity implicates having recurrent problems in memory: such as recalling everyday events, traumatic events, and personal information, accompanied by alterations in consciousness, behaviour, and sensory-motor functioning. Having these symptoms cause significant distress in the common area of functioning; with the absence of parental supervision and talking to himself and the animals, he created an entire world where he lives and plays with his animal friends. Like in the real world of the story, where he has one personality while in his imaginative world, he could have the personality of each of the animals. It seems that he creates each character in his mind to represent a different part of himself. Milne tried to present Dissociative Identity Disorder by hiding it behind this. Christopher's character was a friend with many animals in the tale. His character was based on the real character of Milne's son Christopher. Christopher, the real, was friends with his stuffed animals and always playing with them in the forest as well. With no human interaction whatsoever. The hidden aspects of Christopher's character in the tale are similar to his son in real life.

\section{Eeyore}

Eeyore is a fictional figure in Winnie The Pooh book that was inspired by the original plush toy animal of Christopher Robin Milne. In the book's illustration, Eeyore is presented as an old grey donkey who lives in a small house made of sticks near Winne's house in the Hundred Acre Wood. He has a long tail, but he, unfortunately, lost it once Owl mistook it for a bell-pull; however, Christopher Robin was able to reattach the tail with a pin. Eeyore's. Shea et $a^{\text {xxviii }}$, argued that Eeyore's character might be diagnosed with chronic dysthymia or a 
persistent depressive disorder. People with CD experience these symptoms for twenty-four months of difficulties in concentrating or making decisions, having insomnia or hypersomnia, overeating or poor appetite, muscle fatigue or low energy, feelings of hopelessness and low self-esteem. During those twenty-four months, the symptoms will not fade for more than two months to be clinically diagnosed with Chronic Dysthymia (Mayo Clinic) ${ }^{\mathrm{xxix}}$. Eeyore's character has developed a lot of the previous symptoms of CD in the stories. He is presented as being grumpy in most situations, always depressed with low hope and only expecting bad outcomes to happen; he never showed a positive attitude. He does not even make an effort to be cheerful; he accepts his situation as it is. In the story, an accident has happened to Eeyore where he, unfortunately, lost his tail which was humorous to his animal friends but, because of his CD, he did not find any humour at that moment. In one of the stories "Eeyore Has a Birthday and Gets Two Presents," ${ }^{x x}$ The story began with Eeyore staring at his reflection in the water and calling himself pitiful, throughout the story, his friends kept commenting on how lowspirited Eeyore was, how he always will be. They tried to cheer him up, but their attempt failed.

\section{CONCLUSION}

Ernest Hemingway was remarkably a great American writer and a Nobel prize winner of the twentieth century. His significant style of writing has influenced most of the American writers because his novels were based on personal experience and other people's experiences. Hemingway's career had been through several losses. However, it shined through when he formulated the "Theory of Omission" or "The Iceberg Theory", which states that what is clearly shown in literary works on the surface is, in fact, a hidden mask for what is truly underneath or like an iceberg where the tip is clearly on the surface, but the hidden mass is underneath the water. The theory of omission is consciously or unconsciously influenced by Edgar Allan Poe's Unity of Effect. The Theory of Iceberg/Omission could also be looked at from a psychological perspective where the double parallel entity is represented as the superficial consciousness and the hidden unconsciousness of the human psyche. A. A Milne's war experience has caused him to suffer from a Post Traumatic Disorder that affected him and his life. The trauma haunted his life to the point where he mistook the buzzing sound of the bees to fly bullets. This experience made him realize that as a father he should explain to his young son that after his service in the war and with all what he saw, he cannot help it but to react in this way. Milne drew a beautiful and innocent world where a child had an amazing adventure with his animal friends to cover the harsh and horrible reality of the real world to his son. A. A Milne's Winnie the Pooh is a perfect example of how the theory of the iceberg is demonstrated where the simplicity of the characters, designed by Milne is merely an innocent child-friendly illustration. They hide a dark underside of their nature that could possibly reflect having multiple psychological disorders. Nothing is what it seems.

\section{REFERENCES}

Ammary, Silvia. "Poe's 'Theory of Omission' and Hemingway's 'Unity of Effect." The Edgar Allan Poe Review, vol. 11, no. 2, Sept. 2010, pp. 53-63. (Accessed November 17, 2019).

Bajagain, Umesh. "The Incorporation of Hemingway's Iceberg principle in texts." 2018, Researchgate.net. (Accessed October 10, 2019).

Clinic, Mayo. Generalized Anxiety Disorder. 13 Oct. 2017, https://www.mayoclinic.org/diseases-conditions/generalized-anxiety-disorder/symptomscauses/syc-20360803. (Accessed November 23, 2019). 
Clinic, Mayo. Persistent Depressive Disorder (Dysthymia). 8 Dec. 2018, https://www.mayoclinic.org/diseases-conditions/persistent-depressivedisorder/symptoms-causes/syc-20350929. (Accessed November 23, 2019).

Dohmen, Lizette. "A Bear of Very Little Brain: Positive Psychology Themes in the Stories of Winnie the Pooh." Feb. 2016. (Accessed November 27, 2019).

Editors, Biography.com. "A.A. Milne Biography." The Biography, 2 Apr. 2014, https://www.biography.com/writer/aa-milne. (Accessed November 21, 2019).

Farooq, Ayesha. What Is Hemingway " Ice-Berg Theory ". https://www.academia.edu/33353933/What_is_Hemingway_Ice-Berg_theory_. (Accessed September 30, 2019).

Freud, Sigmund. A General Introduction to Psychoanalysis, trans. Joan Riviere (1922: Clarion Book rpt., New York: Simon \& Schuster, 1969), P. 22. (Accessed November 17, 2019).

Hemingway, Ernest. A Moveable Feast. Charles Scribner's Sons, Dec. 1964. (Accessed October 11, 2019).

Hemingway, Ernest. Death in the Afternoon. Charles Scribner's Sons, 1932. (Accessed October 19, 2019).

Hemingway, Ernest. The Art of the Short Story. 1981. (Accessed October 19, 2019).

Johnston, Kenneth G. "Hemingway and Freud: The Tip of the Iceberg." Journal of Narrative Theory, vol. 14, no. 1, pp. 68-73. (Accessed November 18, 2019).

Lohafer, Susan. "Poe, Hemingway, and Beyond: Importing and Exporting Short Fiction Prototypes." American Studies in Scandinavia, vol. 36, no. 1, 2004. (Accessed October 23, 2019).

MA, Daoshan, and Shuo ZHANG. "A Discourse Study of the Iceberg Principle in A Farewell to Arms." Canadian Academy of Oriental and Occidental Culture, vol. 8, no. 1, pp. 80-84. (September 29, 2019).

Mattick, Lindsay. "The Story of How Winnie the Pooh Was Inspired by a Real Bear - in Pictures." The Guardian, 24 Nov. 2015, https://www.theguardian.com/childrens-bookssite/gallery/2015/nov/24/winnie-the-pooh-inspired-by-a-real-bear. (Accessed November $21,2019)$.

Milne, A.A. Winnie the Pooh. Methuen Publishing Ltd, 1926. (Accessed November 21, 2019).

Milzarski, Eric. "'Winnie the Pooh' Was Created by a Vet Explaining War to His Boy." We Are The Mighty, 1 Aug. 2018, https://www.wearethemighty.com/christopher-robin-milnewinnie-ptsd. (Accessed November 21, 2019).

Pazos, José. "Ernest Hemingway (1899-1961): The Complexity of Simplicity." 2014, Academia.edu.com. (September 29, 2019).

Plimpton, George. "Ernest Hemingway, The Art of Fiction No. 21." The Paris Review, 1958, www.theparisreview.org/interviews/4825/ernest-heminway-the-art-of-fiction-no-21ernest-hemingway. (September 22, 2019).

Poe, Edgar Allan. The Philosophy Of Composition. 1846. (Accessed November 18, 2019).

Savitha, R, and Laxmi Dhar Dwivedi. "The Popular Theories of Hemingway's Time and His Theory of the Art of Fiction." International Journal of Academic Research and Development, vol. 2, no. 6, pp. 1027-1031. (September 30, 2019). 
Shea, S. E., Gordon, K., Hawkins, A., Kawchuk, J., \& Smith., D. (2000). Pathology in the Hundred Acre Wood: a neurodevelopmental perspective on A.A Milne. Canadian Medical Association Journal, 163(12), pp. 1557-1559. (November 28, 2019).

Shih, Alethia. The Intellectual Scale of Children's Fantasy: Telling Ideas in the Works of Lewis Carroll, J.M. Barrie, A.A. Milne, and E.B. White. 2017. (November 22, 2019).

Smith, Paul. "Hemingway's Early Manuscripts: The Theory and Practice of Omission." Journal of Modern Literature, vol. 10, no. 2, Jun. 1983, pp. 268-288. (October 15, 2019).

Smith, Rachel C. Winnie the Pooh Characters and Psychological Disorders. 2015.

Wagner-Martin, Linda. A Historical Guide to Ernest Hemingway. Oxford University Press, Incorporated, Cary, 2000, pp 3-50. (November 30, 2019).

Wood, Daniel. "The Other Seven-Eighths of the Iceberg: Peering Beneath the Surface of Ernest Hemingway's Six-Word Story.” 2009, Academia.edu.com. (September 24, 2019).

Xie, Yaochen. "Hemingway's Language Style and Writing Techniques in The Old Man and the Sea.” English Language Teaching, vol.1, no. 2, 2008. (September 29, 2019).

\footnotetext{
'. Plimpton, Ernest Hemingway, The Art of Fiction interview, No. 21

ii. Plimpton, Ernest Hemingway, The Art of Fiction interview, No. 21

iii. Plimpton, Ernest Hemingway, The Art of Fiction interview, No. 21

iv. Hemingway, The Art of the Short Story, issue 79.

v. Hemingway, Death in the Afternoon, 94,

vi. Poe, The Philosophy of Composition, 2, 3, 5, 7.

vii. Ammary, Poe's 'Theory of Omission' and Hemingway's 'Unity of Effect, 53-63.

viii. Johnston, Hemingway and Freud: The Tip of the Iceberg, 68-73.

ix. Johnston, Hemingway and Freud: The Tip of the Iceberg, 68-73.

×. Hemingway, The Art of the Short Story, issue 79.

xi. Plimpton, Ernest Hemingway, The Art of Fiction interview, issue 79.

xii. Plimpton, Ernest Hemingway, The Art of Fiction interview, issue 79.

xiii. Wood, The Other Seven-Eighths of the Iceberg: Peering Beneath the Surface of Ernest Hemingway's Six-Word Story, 1-3.

xiv. Plimpton, Ernest Hemingway, The Art of Fiction interview, No. 21.

xv. Poe, The Philosophy of Composition, 2, 3, 5, 7.

xvi. Poe, The Philosophy of Composition, 2, 3, 5, 7.

xvii. Poe, The Philosophy of Composition, 2, 3, 5, 7.

xviii. Poe, The Philosophy of Composition, 2, 3, 5, 7.

xix. Johnston, Hemingway and Freud: The Tip of the Iceberg, 68-73.

xx. Freud, A General Introduction to Psychoanalysis, 15.

xxi. Shea, et al., Pathology in the Hundred Acre Wood: a neurodevelopmental perspective on A.A Milne, 15571559.
} 
xxii. Shea, et al., Pathology in the Hundred Acre Wood: a neurodevelopmental perspective on A.A Milne, 15571559.

xxiii. Milne, Winnie the Pooh, 242.

xxiv. Shea, et al., Pathology in the Hundred Acre Wood: a neurodevelopmental perspective on A.A Milne, 15571559.

xxv. Mayo, "Generalized Anxiety Disorder", 1, 2.

xxvi. Milne, Winnie the Pooh, 203-204.

xxvii. Smith, Winnie the Pooh Characters and Psychological Disorders, 6, 12, 21, 22.

xxviii. Shea, et al, Pathology in the Hundred Acre Wood: a neurodevelopmental perspective on A.A Milne, $1557-$ 1559.

xxix. Mayo, "Persistent Depressive Disorder (Dysthymia)", 1, 2.

xxx. Milne, Winnie the Pooh, 122-147. 